\title{
KEBIJAKAN PEMERINTAH DAERAH DALAM PENGELOLAAN PASAR TRADISIONAL DI KOTA PROBOLINGGO
}

\author{
Pungky Praja Jatmika \\ Jurusan Ilmu Administrasi Universitas Jember \\ E-mail : karya.praja.mandiri@gmail.com
}

\begin{abstract}
Condition of traditional markets in the city of Probolinggo are considered uncomfortable for traders and consumers. Many parts of the physical buildings have damaged, lack of trash, sewage that has been closed, lack of lighting and the number of traders who are selling in the hall because they do not get stall.

Vehicles parking around the market has also resulted in traffic congestion as well as vehicles belonging to traders and shoppers that coming / leaving the market. The markets condition as illustrated above, especially in pasar Baru market of Probolinggo city need to get more attention from multiple parties especially market stakeholders and specially from local government as manager. Although local governments have made efforts to empower pasar Baru as a competitive traditional market, the results have not been able to resolve the real problems.

This research is qualitative research with fenomenological approach as it is suitable with social characteristics of traders and traditional market visitors. This research found that the local government of Probolinggo city still need to increase its attention in the improvement of pasar Baru management. These attentions should consider (1) the urgency to increase the cleanliness of the market environment, (2) the urgency of parking rearrangement to overcome the congestion, (3) the urgency of physical revitalization building so that the physical appearance of the building as a modern market, (4) the urgency of revitalization of comprehensive market layout architecture.
\end{abstract}

Keywords : Public Policy, Local Government, Management, Traditional Markets

\section{PENDAHULUAN}

Pengelolaan pasar di Kota Probolinggo belum ada suatu sistem pengelolaan pasar tradisional yang baik sehingga berdampak pada ketidakberdayaan para pelaku usaha dipasar tradisional akibat dari semakin kuatnya pengembangan pasar modern. Pengembangan pasar modern di Kota Probolinggo sangat berpengaruh terhadap pasar tradisional. Hal ini karena pasar modern menyediakan fasilitas yang nyaman, area yang bersih dan penataan zonasi yang baik sehingga pembeli sangat mudah menemukan berbagai kebutuhannya. Kondisi tersebut sangat bertolak belakang dengan pasar tradisional yang justru sebaliknya.

Kondisi pasar tradisional yang ada di kota Probolinggo dianggap tidak nyaman untuk pedagang dan para konsumen. Fisik bangunan pasar kurang sudah rusak, kurangnya tempat sampah, saluran limbah yang telah tertutup, kurangnya pencahayaan dan banyaknya pedagang yang berjualan di lorong karena tidak mendapatkan bedak. Keberadaan pedagang tersebut mengganggu kelancaran access distribusi dan lalulintas pengunjung/pembeli. Hal ini tentu mengurangi daya tarik pengunjung untuk berbelanja di pasar tradisional. Perparkiran di sekitar pasar juga telah mengakibatkan kemacetan kendaraan yang melintas maupun kendaraan milik pedagang dan pebelanja yang menuju / meninggalkan pasar.

Kondisi pasar di atas, khususnya pasar Baru kota Probolinggo perlu mendapatkan perhatian lebih dari berbagai pihak khususnya stakeholder pasar dan pemerintah daerah sebagai pengelola. Meskipun pemerintah 
daerah telah melakukan upaya untuk memberdayakan pasar Baru sebagai pasar tradisional yang kompetitif, namun hasilnya belum mampu mengatasi permasalahan yang ada secara nyata.

Berdasarkan fenomena sebagaimana diuraikan dalam latar belakang maka rumusan masalah penelitian ini adalah " Bagaimana kebijakan Pemerintah Daerah dalam Pengelolaan Pasar Tradisional yang ada di Kota Probolinggo ".

\section{TINJAUAN PUSTAKA}

\section{Kebijakan Pemerintah Daerah dalam Pengelolaan Pasar Tradisional}

Menurut Jimly Asshiddiqie (dalam Marcel Seran. 2014) bahwa dalam konsep negara hukum kesejahteraan, negara dituntut untuk memperluas tanggung jawabnya kepada masalahmasalah sosial ekonomi yang dihadapi oleh rakyat banyak.

Untuk menciptakan kesejahteraan masyarakat pemerintah bertindak sebagai regulator. Untuk itu Pemerintah Kota Probolinggo telah menerbitkan Peraturan Daerah Kota Probolinggo Nomor 9 Tahun 2011 Tentang Perlindungan, Pemberdayaan Pasar Tradisional dan Penataan Pasar Modern.

2. Kebijakan Pemerintah Dalam Menjaga Eksistensi Pasar Tradisional

Upaya pemerintah dalam menjaga eksistensi pasar tradisional sebenarnya sudah mulai nampak dengan adanya wacana-wacana tentang penertiban pasarpasar tradisional agar bisa tertata rapi sehingga nyaman untuk masyarakat, namun wacana tersebut belum bisa berjalan maksimal, karena pada kenyataannya pasar-pasar tradisional yang ada sekarang keadaanya justru masih banyak yang tidak terurus, sehingga kesan pasar tradisonal yang kumuh, bau, tidak terawat masih terngiang dalam benak masyarakat sehingga masyarakat lebih memilih pergi ke pasar-pasar modern yang terkesan bersih, nyaman, wangi dan segar karena menggunakan AC di dalamnya.

Upaya pemerintah dalam menjaga eksistensi pasar tradisional juga terlihat dengan adanya peraturan-peraturan yang dikeluarkan oleh pemerintah. Semangat pemerintah untuk memberikan perlindungan terhadap eksistensi pasar tradisonal telah dibuktikan dengan lahirnya Peraturan Presiden Republik Indonesia (Perpres RI) Nomor 112 Tahun 2007 tentang Penataan dan Pembinaan Pasar Tradisional, Pusat Perbelanjaan dan Toko Modern serta penjabaran teknisnya telah diatur dalam Peraturan Menteri Perdagangan Republik Indonesia (Permendag RI) Nomor : 53/MDAG/PER/12/ 2008 tentang Pedoman Penataan Dan Pembinaan Pasar Tradisional, Pusat Perbelanjaan Dan Toko Modern. Kedua peraturan tersebut merupakan pengejawantahan dari semangat Undang Undang No. 5 Tahun 1999 tentang Larangan Praktek Monopoli dan Persaingan Usaha Tidak Sehat.

\section{Kebijakan Publik dalam Pengelolaan} Pasar Tradisional

Sistem kebijakan, sebagaimana dikemukakan oleh Dunn (dalam Wahyono, 2015), sedikitnya terdiri atas tiga komponen, yaitu komponen pertama: kebijakan publik (public policies), komponen kedua: stakeholders kebijakan (policy stakeholders), dan komponen ketiga: lingkungan kebijakan (policy environment).

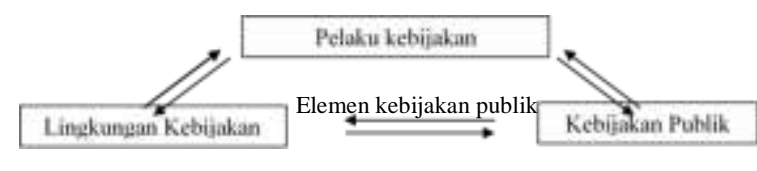

Gambar 1.1 Komponen Kebijakan Publik

Kebijakan publik (public policies) yang merupakan isi kebijakan itu sendiri (policy content) terdiri dari sejumlah daftar pilihan keputusan tentang urusan publik (termasuk keputusan untuk tidak melakukan apa-apa) yang dibuat oleh lembaga dan pejabat pemerintah. Isi 
sebuah kebijakan merespon berbagai masalah publik (public issues) yang mencakup berbagai bidang kehidupan mulai dari pertahanan, keamanan, energi, kesehatan, pendidikan, kesejahteraan dan semacamnya. Tingkat ketepatan keputusan sebuah kebijakan tergantung pada ketepatan dalam merumuskan masalah publik yang ingin dipecahkan.

Tujuan kebijakan publik menurut Rahmat Hidayat (2015) adalah Setiap kebijakan yang dikeluarkan atau ditetapkan oleh pemerintah pasti memiliki tujuan. Tujuan pembuatan kebijakan publik pada dasarnya adalah untuk :

- Mewujudkan ketertiban dalam masyarakat

- Melindungi hak-hak masyarakat

- Mewujudkan ketentraman dan kedaimaian dalam masyarakat

- Mewujudkan kesejahteraan masyarakatat

\section{New Public Management dalam} Pengelolaan Pasar Tradisinoal

New Public Management (NPM) adalah suatu sistem manajemen desentral dengan perangkat-perangkat manajemen baru seperti controlling, benchmarking dan lean management. NPM dipahami sebagai privatisasi sejauh mungkin atas aktivitas pemerintah. NPM secara umum dipandang sebagai suatu pendekatan dalam administrasi publik yang menerapkan pengetahuan dan pengalaman yang diperoleh dalam dunia manajemen bisnis dan disiplin yang lain untuk meningkatkan efisiensi, efektivitas kinerja pelayanan publik pada birokrasi modern.

Prinsip New Public Management

(by Hood, 1991)

a) Lebih berfokus pada manajemen, bukan kebijakan.

b) Adanya standar yang jelas dan dilakukannya pengukuran terhadap kinerja yang dicapainya. c) Penekanan yang lebih besar pada pengendalian atas hasil (output), bukan pada prosedur.

d) Pergeseran kearah adanya tingkat persaingan yang lebih besar didalam sektor pelayanan publik.

e) Penekanan pada pengembangan pola-pola manajemen sebagaimana yang dipraktikan pada sektor swasta untuk mendukung perbaikan kinerja pelayanan publik.

f) Adanya pergeseran ke arah pemecahan ke dalam berbagai unit organisasi yang lebih kecil dalam sektor pelayanan publik.

Penekanan yang lebih besar pada disiplin dan parsimony dalam penggunaan sumber daya.

\section{Pemerintah Daerah Sebagai Pemangku Kebijakan}

Keberadaan pemerintahan pada hakekatnya dimaksudkan untuk melayani dan melindungi kepentingan masyarakat, sekaligus meningkatkan kesejahteraan atau alasan satu-satunya bagi eksistensi negara adalah pelayanan umum. Menurut Lonsdale (Endang Wirjatmi TL, 1996:9) "Pelayanan umum adalah sesuatu yang disediakan baik oleh organisasi pemerintah atau swasta, karena umumnya masyarakat tidak dapat memenuhi kebutuhan yang dilakukan untuk seluruh masyarakat guna kesejahteraan sosial".

Profesionalisme birokrasi yang dituntut oleh good governance tidak terbentuk dengan sendirinya. Haruslah ada upaya sadar untuk mewujudkannya yang seringkali menempuh proses yang panjang. Beberapa strategi dapat disebutkan disini (Tjokrowinoto, 2001: 18) :

1. Role Modelling. Sebagaimana disebutkan, standar perilaku dan pola perilaku birokrat terbentuk antara lain melalui keteladanan. Oleh karena itu sikap elite akan amat 
menentukan sosok profesionalisme birokrasi.

2. Rekruitmen, kondisi kerja dan pelatihan. Proses rekruitmen yang obyektif, kondisi kerja yang konduksif, dan pelatihan yang menggunakan methodik dan dedaktik yang tepat merupakan wacana pembentukan profesionalisme yang efektif.

3. Pendekatan proses belajar. Learning process approach sebagaimana dikemukakan David Korten merupakan wacana yang efektif bagi pembentukan profesionalisme ini. Pendekatan ini memberi margin toleransi yang besar bagi birokrasi untuk berbuat kesalahan (embracing error) dalam proses pembentukan dan penyempurnaan profesionalisme karena kesalahan akan menjadi input untuk perbaikan diri. Melalui kesalahan tadi, birokrat akan belajar efektif (learning to be effective), dan dari sana akan melangkah menuju belajar efisien (learning to be efficient), dan pada akhirnya belajar berkembang (learning to be expand).

4. Pembentukan profesionalisme bagi pengembangan sumber daya birokrasi harus dilakukan secara bersama-sama dengan penguatan organisasi (organizational strengthening) yang memfokuskan diri pada sistem manajemen untuk meningkatkan kinerja pada struktur mikro dan reformasi kelembagaan (institutional reform) yang memfokuskan diri pada struktur makro kelembagaan.

5. Last but no least, pembentukan profesionalisme memerlukan kontrol sosial dari masyarakat sipil. Meskipun nampaknya merupakan kontradiksi, di satu sisi profesionalisme birokrasi menuntut kemampuan empowering masyarakat sipil melalui pembentukan enabling social setting, namun disisi lain, masyarakat sipil perlu melakukan kontrol sosial terhadap birokrasi. Hal ini menuntut mutual learning process antara birokrat dan masyarakat sipil.

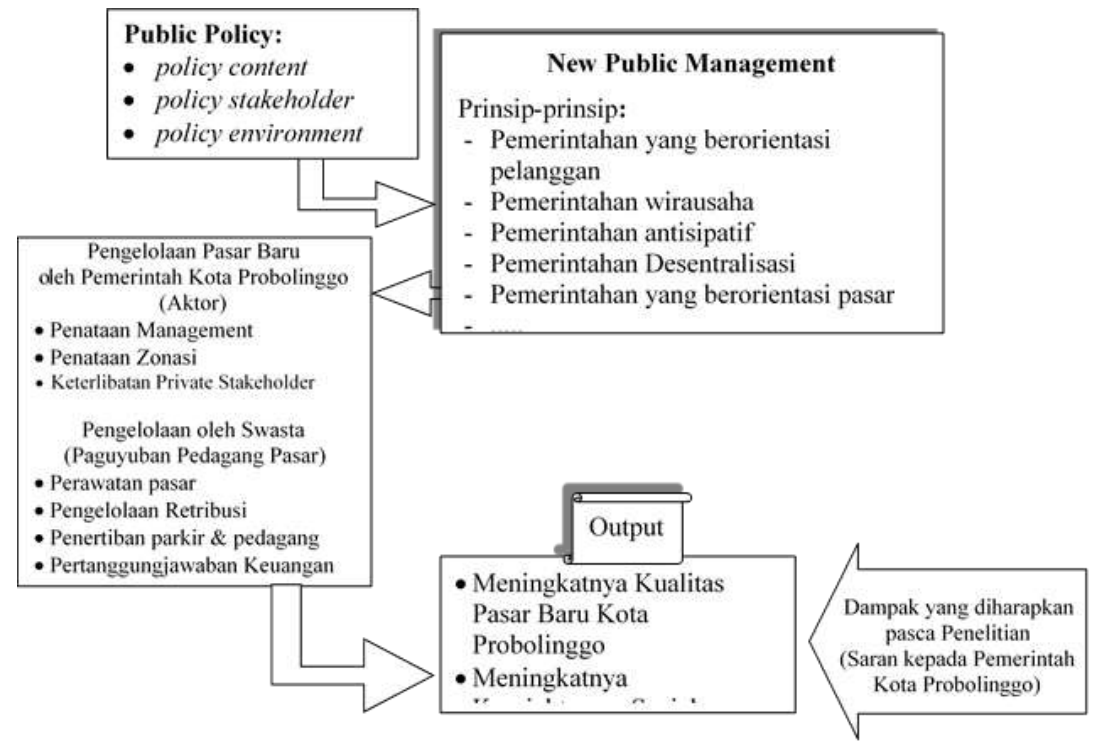

Gambar 1.2 Kerangka Konseptual 


\section{METODE PENELITIAN}

Jenis penelitian yang digunakan dalam penelitian ini adalah penelitian deskriptif kualitatif. Sedangkan pendekatan dalam penelitian ini menggunakan pendekatan fenomenologi. Penelitian dengan menggunakan pendekatan fenomenologi merupakan penelitian yang mendeskripsikan pemaknaan umum dari sejumlah individu terhadap berbagai pengalaman hidup yang terkait dengan fenomena tersebut. Creswell (2014) menyatakan bahwa studi fenomenologis mendeskripsikan pemaknaan umum dari sejumlah indivdu terhadap berbagai pengalaman hidup mereka terkait dengan konsep atau fenomena.

Jenis penelitian ini sesuai dengan fenomena yang berkembang di masyarakat bahwasannya pasar tradisional khususnya pasar Baru kota Probolinggo semakin tidak nyaman bagi pedagang dan pengunjung/pembeli serta masyarakat pengguna jalan protokol sekitar pasar Baru.

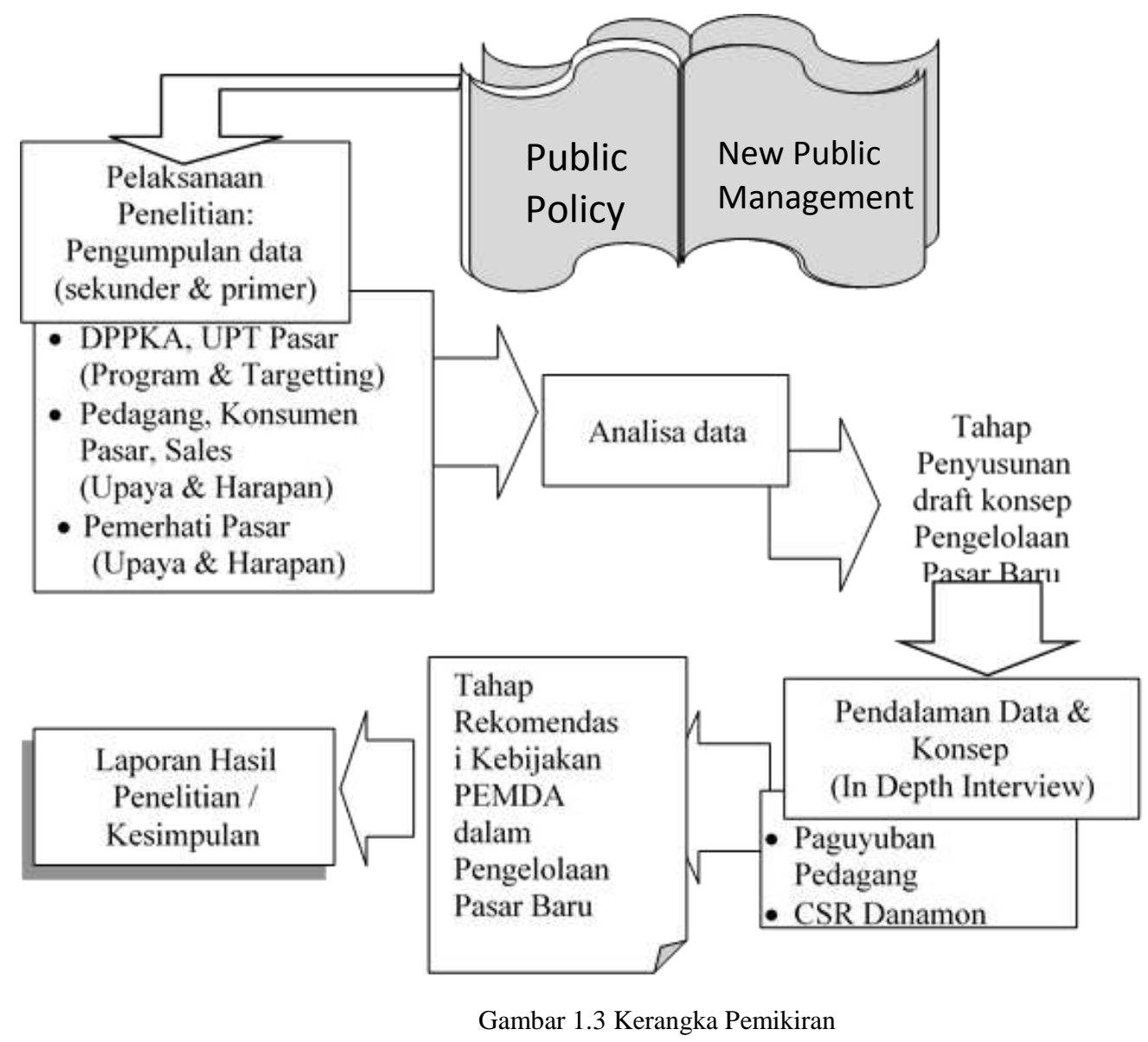


HASIL DAN PEMBAHASAN

\section{Kebijakan Pemerintah Daerah Kota Probolinggo}

Kebijakan Pemerintah Daerah

Kota Probolinggo dalam Penyediaan

Sarana Prasarana Pasar Baru Kota Probolinggo Dari hasil analisis berdasarkan berbagai data primer, sekunder, wawancara dan pengamatan di lokasi diketahui bahwa pemerintah kota Probolinggo sebagai pembuat kebijakan yang berwenang mengelola pasar Baru sebagai sebuah lembaga perekonomian publik yang mana pasar Baru sebagai pasar tradisional, yang dalam UndangUndang Nomor 7 tahun 2014 tentang Perdagangan disebut dengan Pasar Rakyat, pemerintah kota Probolinggo melalui Unit Pelaksana Teknis (UPT) Pasar Baru telah menyediakan beberapa sarana.

Kebijakan Pemerintah Daerah Kota Probolinggo dalam Pembentukan Kelembagaan bagi Pedagang Pasar Baru Kota Probolinggo. UPT Pasar Baru telah memfasilitasi terbentuknya beberapa organisasi informal di dalam pasar yang antara lain :

a) Paguyuban Pedagang pasar Baru Kota Probolinggo

Terbentuknya organisasi yang beranggotakan para pedagang pasar Baru yang kemudian disebut dengan paguyuban pedagang pasar Baru ini didasarkan pada SK Kepala UPT Pasar Baru Kota Probolinggo Nomor : 188/35a/KEP/425.110.1/2016

Tentang Susunan Kepengurusan paguyuban pedagang pasar Baru di kota Probolinggo Tahun 2016.

b) Bank Sampah Pasar Baru

Pembentukan bank sampah di pasar Baru merupakan salah satu hasil musyawarah dari pengurus paguyuban pedagang pasar Baru dan menjadi salah satu kegiatan nyata dari paguyuban untuk menyiasati terpeliharanya kebersihan pasar. Fasilitasi terbentuknya bank sampah ini merupakan salah satu langkah strategis pemerintah kota Probolinggo untuk mewujudkan kebersihan pasar Baru. Dengan adanya bank sampah ini harapan pemerintah kota Probolinggo para pedagang pasar Baru semakin termotivasi kepeduliannya dalam menjaga kebersihan lingkungan pasar.

c) Radio Land Pasar Baru

Radio Land adalah sebuah sistem penyiaran informasi dan hiburan melalui suatu studio sederhana layaknya sebuah stasiun radio. Radio Land ini sangat efektif sebagai sarana menyampaikan program-program yang diadakan oleh paguyuban pedagang, pemerintah maupun programprogram kegiatan lainnya sehingga dapat mempercepat sampainya informasi kepada seluruh pedagang dan khalayak pasar. Beberapa pedagang juga menyatakan bahwa keberadaan radioland pasar Baru dapat dijadikan sebagai sarana curhat dan memperoleh informasi cepat dari paguyuban ataupun dari pemerintah.

2. Upaya-upaya yang telah dilakukan oleh Pemerintah Daerah Kota Probolinggo

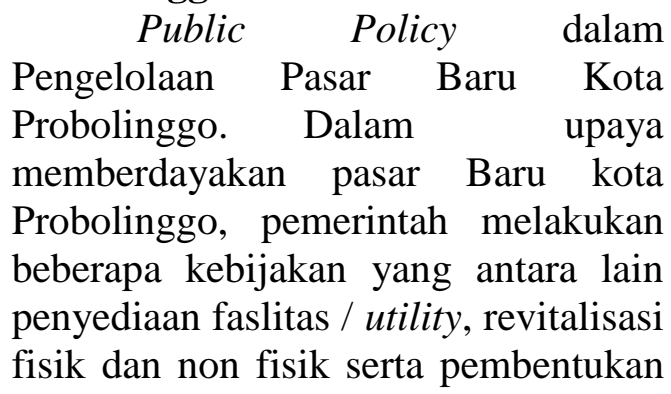


wadah-wadah komunikasi yang berbentuk organisasi informal.

Upaya pembentukan organisasi-organisasi informal seperti paguyuban pedagang pasar Baru, pembentukan bank sampah oleh paguyuban pedagang pasar serta pendirian Radio Land Suara Pasar yang juga merupakan produk kegiatan paguyuban pedagang pasar Baru tersebut merupakan salah satu wujud implementasi kebijakan publik yang dilakukan oleh pemerintah daerah kota Probolinggo. Langkah-langkah tersebut sesuai dengan adanya tiga komponen kebijakan publik yang diungkapkan oleh Dunn (dalam Wahyono, 2015), yaitu isi kebijakan (policy content), stakeholders kebijakan (policy stakeholders), dan lingkungan kebijakan (policy environment).

Alur Pembuatan Kebijakan

Pengelolaan Pasar Baru Kota Probolinggo

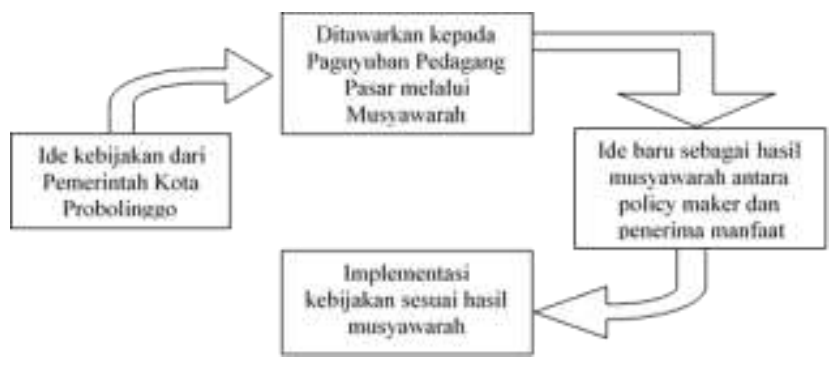

New Public Management dalam Pengelolaan Pasar Baru Kota Probolinggo. Penerapan lima prinsip NPM dalam konteks pengelolaan pasar Baru kota Probolinggo oleh pemerintah kota Probolinggo :

a) Korelasi dibentuknya Paguyuban Pedagang Pasar Pasar Baru dengan prinsip Pemerintahan yang Berorientasi Pelanggan pada New Public Management ;

Terwujudnya kepuasan pelayanan akan dapat tercapai jika aspirasi masyarakat berupa usulan keinginan, kebutuhan dan pendapatnya tentang pengelolaan pasar Baru oleh UPT Pasar yang disalurkan melalui wadah paguyuban pedagang pasar Baru dapat dipenuhi dan diwujudkan oleh pemerintah kota Probolinggo sehingga tercapai kesejahtaraan para pedagang dan pelanggan pasar yang ada.

b) Korelasi dibentuknya Paguyuban pedagang Pasar dengan prinsip Pemerintahan Desentralisasi pada New Public Management;

Pemerintah Kota

Probolinggo dalam membuat kebijakan dalam pengelolaan pasar Baru tidak secara mutlak direncanakan sendiri oleh pihak pemerintah daerah namun juga melibatkan langsung masyarakat sebagai penerima manfaat dari kebijakan yang dibuat melalui organisasi / lembaga informal yaitu Paguyuban pedagang yang ada di dalam pasar dimaksud.

c) Korelasi dibentuknya lembaga Bank Sampah di Pasar Baru Kota Probolinggo dengan ke-5 Prinsip New Public Management;

Terkait dengan pembentukan bank sampah oleh paguyuban pedagang pasar, pemerintah kota Probolinggo telah memposisikan diri sebagai Pemerintahan Yang Berorientasi Pelanggan, yang merupakan salah satu prinsip pelaksanaan dari New Public Management, dimana manfaat dari pengelolaan sampah dapat dinikmati hasilnya oleh pemilik sampah itu sendiri yaitu para pedagang pasar sebagai penghasil sampah sekaligus pihak yang menikmati dampak positif dari bersihnya lingkungan pasar karena termotivasi adanya keuntungan ekstra dari 
pengelolaan sampah melalui bank sampah yang telah menjadi jembatan bagi para pedagang dalam memanfaatkan sampah yang ada.

d) Korelasi dibentuknya Radio Land Suara Pasar Baru dengan ke-5 Prinsip New Public Management

Sebagai upaya menyediakan media penyebaran informasi baik informasi yang berasal dari pemerintah daerah maupun informasi yang bersifat internal komunitas pedagang pasar Baru, maka dibentuklah Radio Land Suara Pasar Baru yang dilahirkan dari hasil musyawarah pengurus paguyuban pedagang pasar Baru kota Probolinggo. Secara umum keberadaan Radio Land khusus untuk para pedagang dan pengunjung pasar tradisional ini sangat baik. Bahkan di salah satu pasar tradisional telah dijadwalkan adanya siaran khusus pencerahan rohani yang dilaksanakan secara bekerjasama dengan salah satu organisasi masyarakat yang dengan sukarela memberikan bantuan yang dikemas dalam bentuk suatu acara radio dengan judul Berdagang sambil Ngaji yang berisi Ceramah Agama Islam dan tanya jawab permasalahan perdagangan yang dialami oleh para pedagang pasar ditinjau dari sudut pandang Agama Islam.
3. Solusi Kebijakan Kemitraan Pengelolaan Pasar Tradisional di Kota Probolinggo

\section{a. Renovasi Fisik Bangunan}

Terkait dengan kurang sinkronnya antara fakta hasil tatakelola kondisi pasar dengan pendapatan retribusi maka beberapa pihak merasa perlu adanya langkah konkrit yang lebih paripurna dalam pemberdayaan pasar tradisional khususnya pasar Baru yaitu dengan melakukan renovasi fisik pasar.

Renovasi fisik pasar Baru yang dikehendai oleh berbagai pihak adalah dalam wujud mengubah tata ruang pasar, baik tata ruang penempatan los/lapak pedagang maupun tata ruang parkir yang terpadu, misalnya berada di lantai dasar, sehingga kemacetan lalulintas di jalan protokol bisa teratasi dan lalulintas bongkar muat barang lebih nyaman. Jika perlu justru dibangun eskalator dari lantai dasar ke lantai berikutnya sehingga meringankan para pedagang menganggut barang ke atas. Pada dasarnya banyak pihak menginginkan tata ruang lingkungan pasar Baru yang lebih terintegrasi dan membuat semua pihak lebih nyaman baik dalam berdagang maupun berbelanja.

Ketersediaan tempat penampungan sampah sementara ini tentu terkait erat dengan desain fasilitas bangunan fisik pasar yang belum mengantisipasi volume sampah yang ternyata sangat banyak. Maka dari itu sudah sangat mendesak untuk segera dilakukan renovasi fisik bangunan dengan mendesain ulang pasar Baru yang bisa mengakomodir volume sampah, jumlah pedagang 
dan penataan lokasi parkir yang integratif dan representatif.

b. Penataan dan Penertiban Perparkiran

Penggunaan badan jalan sebagai tempat parkir, baik oleh kendaraan roda enam, roda empat, roda tiga, becak dan roda dua (sepeda motor dan sepeda) memang tidak bisa dielakkan karena jumlah kendaraan yang sangat banyak akibat dari banyaknya pedagang dan pengunjung pasar yang memarkir kendaraannya baik saat bongkar muat barang dagangan maupun para pengunjung yang sedang berbelanja di pasar Baru. Selain itu juga disebabkan karena lahan khusus parkir tidak disediakan oleh pemerintah daerah.

Dengan pertimbangan kondisi demikian maka sudah saatnya dilakukan renovasi fisik pasar yang didesain dapat mengakomodasi perparkiran sehingga permasalahan kesemrawutan lalu lintas dan perparkiran dapat teratasi secara komprehensif.

\section{c. Penertiban Pedagang di Luar} Pasar

Dari data primer diperoleh 83 pedagang yang masih menempati tepi jalan akses dan pinggir pasar. Mereka sebagian besar berada di sepanjang trotoar sisi Barat dan Utara pasar Baru. Sebagiannya menempati tepi kiri dan kanan pintu masuk dan lorong dalam pasar.

Pedagang yang berada di sisi Barat dan sisi Utara pasar Baru sudah barang tentu berada di depan toko. Pedagang yang di depan toko ini tentu mengganggu lalu lintas pengunjung pasar/pembeli yang akan memasuki pasar dan merugikan toko yang ada di sisi Barat dan sisi Utara tersebut karena pembeli cenderung menghindari kerumunan pedagang tak berlapak ini. Dengan demikian pemilik toko merasa dirugikan oleh keberadaan pedagang tersebut.

Selain merugikan toko tersebut, pedagang yang tidak memiliki tempat permanen ini juga merugikan para pedagang di dalam pasar yang resmi memiliki lapak dan telah membayar retribusi sewa lapak di dalam pasar secara rutin. Karena jenis dagangan yang dijajakan sama dengan dagangan yang dijual oleh pedagang yang ada di dalam pasar.

Adanya luberan pedagang pasar yang berjualan di luar pasar ini sudah sering disampaikan oleh para pedagang anggota paguyuban pedagang pasar Baru, namun kenyataannya hingga sekarang masih belum terselesaikan. Hal ini tentunya menjadi kesenjangan yang tak berujung, karena dalam pertemuan sering di bahas namun kenyataannya tidak ada solusi realistis yang sesuai dengan harapan pedagang yang telah disampaikan pada setiap kali pertemuan dan solusinya belum dapat dirasakan oleh para anggota paguyuban pedagang pasar karena masih tetap banyak pedagang di luar pasar.

\section{KESIMPULAN}

Pemerintah Daerah Kota Probolinggo masih perlu membuat kebijakan alternatif sebagai solusi dalam pengelolaan Pasar Baru di Kota Probolinggo. Upaya yang telah dilakukan Pemerintah Daerah Kota Probolinggo dalam pengelolaan Pasar Baru sebenarnya sudah dilaksanakan baik tentang 
pembangunan fisik pasar maupun non fisik pasar, akan tetapi beberapa permasalahan dalam pengelolaan pasar baru masih belum terselesaikan dengan baik karena masih adanya kondisi pasar yang masih kumuh/becek saat musim hujan, parkir dan jalan sekitar pasar masih semrawut dan banyaknya pedagang yang berada di luar pasar untuk menjual dagangannya.

Pemerintah Daerah Kota Probolinggo perlu mewujudkan harapan masyarakat, pedagang dan warga pasar demi mensejahterakan mereka dengan melibatkan pengelolaan pasar tradisional tersebut dengan pihak swasta yaitu paguyuban pedagang pasar. Perubahan pengelolaan pasar tradisional ini sangat mendesak yang diawali dengan revitalisasi baik bangunan fisik dan non fisik serta arsitektur tata letak pasar sehingga tampang fisik gedung layaknya pasar modern agar pengunjung atau konsumen betah untuk berada di pasar baru. Pelibatan paguyuban pedagang pasar dimaksudkan untuk segera mengatasi permasalahan yang belum teratasi sehingga segera menjadikan pasar tradisional menjadi pilihan utama bagi masyarakat dalam berbelanja sehingga diharapkan dapat bersaing secara sehat dengan pasar modern.

Solusi ini sesuai dengan model NPM dengan melibatkan pihak swasta dalam pengelolaan pasar tradisional sebagai wujud pemerintahan yang menjalankan prinsip wirausaha.

Sebagaimana telah ditetapkan dalam tujuan penelitian ini bahwa salah satu tujuan dilaksanakannya penelitian ini adalah untuk memberikan solusi pengelolaan pasar tradisional kepada Pemerintah Daerah Kota Probolinggo, maka peneliti memberikan saran hendaknya pemerintah Kota Probolinggo segera melakukan revitalisasi bangunan secara menyeluruh. Revitalisasi fisik dilakukan sedemikian rupa sehingga dapat menjadikan performan pasar tradisional pasar Baru memiliki profil sebagaimana pasar swalayan modern. Dalam penataan ulang bangunan fisik Pemerintah Kota Probolinggo hendaknya memberikan ruang parkir yang cukup sebagaimana dikehendaki oleh masyarakat sehingga memberikan efek nyaman kepada para pengunjung. Setelah dilakukan renovasi fisik pasar seyogyanya pengelolaan pasar dilakukan oleh paguyuban pedagang pasar. Dalam pengelolaan tersebut paguyuban pedagang pasar melakukan pengelolaan retribusi sewa los, tetribusi perparkiran, perawatan bangunan pasar, lingkungan, penertiban

\section{DAFTAR PUSTAKA}

Afiff, Faisal. 2015. Kebijakan Bisnis. Jakarta: Universitas Bina Nusantara.

Adi, Bawana. 2009. Perencanaan Pelayanan Perizinan Investasi Dalam Rangka Meningkatkan Kualitas Pelayanan Perizinan. Malang: Universitas Brawijaya.

Badan Pusat Statistik. 2015. Kota Probolinggo Dalam Angka 2015. Kota Probolinggo: BPS.

BAPPEDA. 2012. Program Revitalisasi Pasar Baru kota Probolinggo. Pemerintah Kota Probolinggo.

BAPPEDA. 2013. Profil Umum Pasar Baru Kota Probolinggo. Pemerintah Kota Probolinggo.

Bungin, M Burhan. 2014. Penelitian Kualitatif : Komunikasi, Ekonomi, Kebijakan Publik dan Ilmu Sosial Lainnya. Jakarta: Prenada Media Group.

Creswell, John. 2014. Penelitian Kualitatif \& Desain Riset, Memilih di antara Lima Pendekatan, Edisi ke-3. Yogyakarta: Pustaka Pelajar.

Djumantri. 2010. Pasar Tradisional, Ruang Masyarakat Tradisional Yang Terpinggirkan. Buletin Tata Ruang, Juli-Agustus 2010. E-Jurnal. Manado: Universitas Samratulangi. 
Falianti. 2011. Desain Kebijakan Publik Dalam Menghadapi Krisis Global. Jurnal Ekonomi \& Kebijakan Publik, Vol. 2, No. 2, Desember 2011.

Febrianty, Dessy. 2013. Model of Role Strengthening of Traditional Market Based on Social Capital in Indonesia: Study Case Beringharjo Market. Journal of Economics and Sustainable Development. Jogjakarta: Vol.4, No. 5, 2013 www.iiste.org.

Girindrawardana, Danang. 2015. Public Services Reform in Indonesia. Jakarta: Ombudsmen Republik Indonesia. (diakses pada tanggal 7 April 2016).

Goleman Daniel, Boyatzis Richard, Mckee Annie, 2006. Kepemimpinan Berdasarkan Kecerdasan Emosi. Jakarta: P.T. Gramedia Media Utama.

Himawan, Muhammad. 2016. Kajian Hubungan Teori Pasar Dengan Administrasi Publik. https://www.academia.edu. (diakses pada tanggal 12 Oktober 2016).

Indrawati, Novita. 2010. Penyusunan Anggaran Dalam Era New Public Management: Implementasinya di Indonesia, Jurnal Riset Akuntansi dan Bisnis Vol 10 No. 2. Medan: Universitas Muhammadiyah Sumatera Utara.

Ismail. 2009. Etika Birokrasi Dalam Perspektif Manajemen Sumber Daya Manusia. Averroes Press.

Islamy, Irfan. 2009. Prinsip-prinsip Perumusan Kebijakan Negara. Surabaya: Universitas Negeri Surabaya.

Kim, Heung-Ryel. 2015. Culture and Tourism-Oriented Local
Traditional Market Strategies in Korea. Korea: MokWon University.

Kosasih, 2014. Pasar Tradisional: Ruang Publik yang Makin Terpinggirkan. Jurnal Ilmiah, Bandung: Universitas Pendidikan Indonesia.

Kotler dan Lee. 2007. Pemasaran di Sektor Publik. Jakarta: PT. Indeks.

Mairizon dan Kiswanto. 2013. Implementasi Fungsi-Fungsi Manajemen Publik, Jurnal Kebijakan Publik, Volume 4, Nomor 2.

Mangkoesebroto, Guritno. 1999. Ekonomi Publik. Yogyakarta: BPFE.

Mangeswuri dan Purwanto. 2010. Revitalisasi Pasar Tradisional Di Indonesia. Jurnal Ekonomi \& Kebijakan Publik. Vol. 2 No. 1, Desember 2010.

Miles dan Huberman. 1992. Analisis Data Kualitatif. Jakarta : Universitas Indonesia.

Monoarfa. 2012. Efektivitas dan Efisiensi Penyelenggaraan Pelayanan Publik: Suatu Tinjauan Kinerja Lembaga Pemerintahan. Jurnal Pelangi Ilmu Vol.05 No. 01. http://ejurnal.ung.ac.id/index.php/J PI/article/view/891. (diakses tanggal 7 April 2016)

Moleong, Lexy J. 2007. Metodologi Penelitian Kualitatif. Bandung : PT Remaja Rosdakarya.

Mujianto, Agus. 2015. Mengenal Kebijakan Publik. Pusdiklat Kemenkeu R.I. Jakarta.

http://www.bppk.kemenkeu.go.id. (diakses pada tanggal 12 Juli 2016).

Mulyono, Agus. 2015. Mengenal Kebijakan

Publik. Pusdiklat Kemenkeu.

Jakarta. http://rochyati-w-t-

fisip.web.unair.ac.id/artikel_detail69582-Umum

MENGENAL\%20IMPLEMENTA SI\%20KEBIJAKAN\%20PUBLIK \%20.html. (diakses pada tanggal 12 Juli 2016) 
Muniggar, Retno. 2014. Pengantar Ilmu Kebijakan.

http://himafarin.lk.ipb.ac.id. (diakses pada tanggal 4 Agustus 2016)

Nystrom, H. 2013. Definisi pasar menurut para ahli. http://www.dosenpendidikan.com/p engertian-pasar-menurut-para-ahlibeserta-jenis-jenisnya. (diakses pada tanggal 1 Agustus 2016)

Nastiti, Surti. 2013. Pasar di Jawa Masa Mataram Kuna Abad VIII-XI Masehi. Jakarta: Dunia Pustaka Jaya

Paskarina, Mariana, Atmoko. 2007. Evaluasi Kebijakan Pengelolaan Pasar di Kota Bandung. Pusat Penelitian Kebijakan Publik dan Pengembangan Wilayah, Bandung: Lembaga Penelitian Universitas Padjadjaran.

Prastyawan, Suryono, Soeaidy, Muluk. 2015. Revitalization of Traditional Markets into a Modern Market in the Perspective of Local Governance Theory (Studies on Revitalization Wonokromo Market in Surabaya). IOSR Journal Of Humanities And Social Science (IOSR-JHSS).Volume 20, Issue 9, Ver. IV. http://iosrjournals.org/iosrjhss/papers/Vol20-issue9/Version4/A020940106.pdf.

Rudianto, Yayan. 2005. Pelayanan Publik Pada Penyelenggaraan Pemerintah Kecamatan. Jurnal Madani Hal.32 Edisi II/Nopember 2005. (diakses tanggal 5 April 2016).

Sanjaya, Adi. 2015. Pengertian Kebijakan Publik dan Pemerintah Definisi Menurut Para Ahli serta Komponennya. http://www.landasanteori.com. (diakses pada tanggal 5 April 2017)
Seran, Marcel. 2014. Perlindungan Hukum Bagi Pasar Tradisional di Era Globalisasi Dan Liberalisasi Perdagangan. MMH, Jilid 43 No. 3 Hal. 388: Juli 2014. Makassar: Fakultas Hukum Universitas Atma Jaya.

Starkey, Phyllis. 2009. Paper Conference: Market Failure?: Can the traditional market survive? London: House of Commons London. (diakses pada tanggal 2 Februari 2017)

Sugiyono. 2015. Memahami Penelitian Kualitatif. Bandung: Alfabeta.

Susilo, Dwi. 2011. Dampak Operasi Pasar Modern Terhadap Pendapatan Pedagang Pasar Tradisional Di Kota Pekalongan. Pena Jurnal Ilmu Pengetahuan dan Teknologi hal. 29. Journal.unikal.ac.id. (diakses pada tanggal 24 Januari 2016)

Tangkilisan, Nogi. 2005. Manajemen Publik. Jakarta: PT. Grasindo.

Thamrin, Mahandis Y. 2013.Petualangan Melancongi Pasar Zaman Mataram Kuno. National Geographic Indonesia.

Tjokrowinoto, Moeljarto. 2001. Birokrasi Dalam Polemik. Yogyakarta: Pustaka Pelajar.

Utami dan Riduansyah. 2013. Pengelolaan Pasar Tradisional di Kota Depok. Jakarta: Universitas Indonesia.

Wahyono, Budi. 2015. Sistem dan Komponen Kebijakan Publik. http://www.pendidikanekonomi.co $\underline{\mathrm{m} / 2015 / 01 / \text { sistem-dan-komponen- }}$

kebijakan-publik.html. (diakses pada tanggal 12 Juli 2017)

Wainwright, Hilary. 2012. Tragedi Privatisasi Potensi Publik. Public Services International dan Transnational Institute. Voltaire CedexFrance.

Wicaksono, Harsasto, Astuti. 2013. Persepsi Pedagang Pasar Terhadap Program Perlindungan Pasar Tradisional Oleh Pemerintah Kota 
Semarang. Journal of Politic and Government Studies Volume 2, Nomor 4,Tahun 2013.

Wilson, Kharisma. 2012. Sungai Banger Menjadi Awal Terbentuknya Daerah Probolinggo. Nee Prinses.

Winarno, Budi. 2014. Kebijakan Publik (Teori, Proses dan Studi Kasus), Yogyakarta: Center of Academic Publishing Service.

Wirjatmi, Endang. 2001. Filosofi Strategi Dan Teknik Pelayanan Prima Di Sektor Publik, Bandung: Lembaga Administrasi Negara.

Yusuf, Muri. 2014. Metode Penelitian (Kuantitatif, Kualitatif \& Penelitian Gabungan). Jakarta: Prenadamedia Group.

Undang-Undang Republik Indonesia Nomor 25 tahun 2009 tentang Pelayanan Publik. Jakarta: Pemerintah Republik Indonesia.

--------. 2014. Undang-undang Republik Indonesia Nomor 23 tahun 2014 tentang Pemerintahan Daerah.

2014. Undang-undang Republik Indonesia Nomor 7 tahun 2014 tentang Perdagangan.

--------. 2007. Peraturan Presiden No.112 tahun 2007 tentang Penataan dan Pembinaan Pasar Tradisional, Pusat Perbelanjaan dan Toko Modern.

--------. 2011. Peraturan Daerah Probolinggo Nomor 9 Tahun 2011 Tentang Perlindungan, Pemberdayaan Pasar Tradisional dan Penataan Pasar Modern. 2014. Peraturan Menteri Perdagangan. Pemerintah Republik Indonesia. 